\title{
Advertisement and courtship calls of Dendropsophus nanus (Boulenger, 1889) (Anura: Hylidae) from its type locality (Resistencia, Argentina)
}

\author{
Bernardo Franco da Veiga Teixeira ${ }^{1,2, *}$, Víctor Hugo Zaracho ${ }^{3}$ \& Ariovaldo Antonio Giaretta ${ }^{2}$ \\ ${ }^{1}$ Programa de Pós-graduação em Biologia Comparada, Universidade de São Paulo, Departamento de Biologia, \\ Avenida dos Bandeirantes, 3900, 14040-901, Ribeirão Preto, SP, Brazil. \\ ${ }^{2}$ Laboratório de Taxonomia, Sistemática e Ecologia Comportamental de Anuros Neotropicais, \\ Faculdade de Ciências Integradas do Pontal, Universidade Federal de Uberlândia, Rua 20 no 1.600, \\ Bairro Tupã, 38304-402, Ituiutaba, MG, Brazil. \\ ${ }^{3}$ Laboratorio de Herpetología. Facultad de Ciencias Exactas y Naturales y Agrimensura, \\ Universidad Nacional del Nordeste. Av. Libertad 5470. (3400) Corrientes, Argentina. \\ *Corresponding author: e-mail: teixeirabfv@gmail.com
}

TEIXEIRA, B.F.V., ZARACHO, V.H., GIARETTA, A.A. Advertisement and courtship calls of Dendropsophus nanus (Boulenger, 1889) (Anura: Hylidae) from its type locality (Resistencia, Argentina). Biota Neotropica. 16(4): e20160183. http://dx.doi.org/10.1590/1676-0611-BN-2016-0183

\begin{abstract}
Dendropsophus nanus was described from Resistencia, Argentina. The species distribution is widespread in South America east of the Andes. Despite its wide distribution, little information about its advertisement call is available in the literature. Call descriptions from type localities are especially important for the resolution of taxonomic issues, as well as for intraspecific comparisons. Herein we describe the advertisement and the male courtship calls of D. nanus from its type locality. The advertisement call of D. nanus is composed of two types of pulsed notes, herein referred to as "note A" (long note) and "note B" (short note), both with similar dominant frequencies, but different durations. The courtship call is formed by notes that are similar to notes A of the advertisement call, but emitted at lower amplitude. Previous studies demonstrated that the complex call of Eleutherodactylus coqui and Geocrinia victoriana convey separated messages to male and female. Although several previous experiments have been conducted to assess the acoustic interactions of some species of Dendropsophus, more studies are necessary to understand the functions of the two notes of the advertisement call of D. nanus and the calls of other species of the D. microcephalus group.
\end{abstract}

Keywords: Acoustic communication; Dendropsophus microcephalus group; Behavior.

\section{Cantos de anúncio e corte de Dendropsophus nanus (Boulenger, 1889) (Anura: Hylidae) de sua localidade tipo (Resistencia Argentina).}

Resumo: Dendropsophus nanus foi descrito de Resistencia, Argentina. Essa espécie está amplamente distribuída na América do Sul a leste dos Andes. Apesar da ampla distribuição, poucas informações sobre seu canto de anúncio estão disponíveis em literatura. Descrições de cantos de localidades tipo são especialmente importantes para a resolução de problemas taxonômicos, assim como para comparações intraespecíficas. Aqui, nós descrevemos os cantos de anúncio e de corte do macho de D. nanus de sua localidade tipo. O canto de anúncio de D. nanus é composto por dois tipos de notas, aqui referidas como "notas A" (nota longa) e "notas B" (nota curta), ambas com frequência dominante similar, mas com diferenças nas durações. O canto de corte é formado por notas que são similares à nota A do canto de anúncio, mas emitidas com menor amplitude. Estudos anteriores demonstraram que os cantos complexos de Eleutherodactylus coqui e Geocrinia victoriana transmitem mensagens separadas para machos e fêmeas. Embora vários experimentos anteriores terem sido realizados a fim de avaliar as interações acústicas de algumas espécies de Dendropsophus, mais estudos são necessários para entender as funções das duas notas do canto de anúncio de D. nanus e dos cantos de outras espécies do grupo de D. microcephalus.

Palavras-chave: Comunicação acústica, Grupo de Dendropsophus microcephalus, Comportamento. 


\section{Introduction}

Sound production by animals is primarily a method of advertising the presence of an individual to another. In Anura, the vocalizations are produced especially by males. The categories of anuran calls are recognized based on the context in which they are emitted, such as advertisement call, courtship call, territorial call, release call, among others. The advertisement calls, main type of sound produced by anuran males, has two functions: (1) the attraction of a conspecific females, and (2) the announcement of an occupied territory to other conspecific and heterospecific males (Duellman $\&$ Trueb 1986, Wells 2007). The two primary functions of the advertisement call may be combined into one monophasic signal, which conveys separate messages to males and females, or they may be separated between the components of a diphasic call. In the case of diphasic calls, the notes are combined within a single unit or produced in a sequence (Littlejohn 1977).

Dendropsophus nanus was described by Boulenger (1889) from Resistencia, Argentina. The species distribution is widespread in South America east of the Andes (Frost 2015). Despite its wide distribution, little information on its advertisement call is available in the literature. Brief descriptions were provided by Barrio (1967), Basso et al. (1985), and Marquez et al. (1993), and, more recently, Martins \& Jim (2003) recognized that the advertisement call of $D$. nanus was actually composed of two types of notes (diphasic call) that differed in duration and pulse number.

Call descriptions from type localities are especially important for the resolution of taxonomic issues, as well as for intraspecific comparisons. Herein we describe the advertisement call, and for the first time, the male courtship call of D. nanus from its type locality (Resistencia, Argentina).

\section{Material and Methods}

Fieldwork was carried out on 11 January 2011. Calls were recorded between $20: 13-21: 08 \mathrm{~h}$ (air temperature $25^{\circ} \mathrm{C}$, water temperature $26^{\circ} \mathrm{C}$ ) using a M-Audio Microtrack II digital recorder set at a sampling rate of $48 \mathrm{kHz}$ and an amplitude resolution of 16 bits, coupled to a ME66/K6 directional microphone. Acoustic traits were analyzed using Raven Pro 1.4 for Windows from The Cornell Lab of Ornithology (Bioacoustic Research Program 2012); spectrogram settings were: window type $=$ Hann, window size $=1024$ samples, $3 \mathrm{~dB}$ bandwidth $=270 \mathrm{~Hz}$, overlap $=85 \%$, hop size $=0.792 \mathrm{~ms}$, DFT size $=1024$ samples, and grid spacing $=46.9 \mathrm{~Hz}$. All other settings followed the 'default' of Raven. Temporal traits were measured from oscillograms and spectral traits were measured from spectrograms. Six acoustic variables were measured: note duration, number of pulses per note, pulse duration, dominant frequency (obtained through the Peak Frequency measurement function), pulse rate (quantified as the number of pulses divided by note duration), and call rate in the case calls were emitted in series (quantified as the number of notes divided by note series duration). Sound figures were obtained in the Seewave package v. 2.0.2 (Sueur et al. 2008), on the R platform (version 3.2.2) (R Core Team 2015); Seewave settings were Hanning window, 256 samples (FFT), and $85 \%$ of overlap. Call terminology follows Duellman \& Trueb (1986). Voucher specimens are housed in the Collection of frogs at the Universidad Nacional del Nordeste (UNNEC), Corrientes, Argentina, under the following numbers: UNNEC 12429-39.

\section{Results}

The advertisement call of D. nanus (Figure 1) is composed of two types of pulsed notes (diphasic call), herein referred to as "note A" (long note) and "note B" (short note), both with similar dominant frequencies. Calls are often emitted in series from 2 to 6 notes (mean 2.4; $\mathrm{SD}=0.4 ; \mathrm{N}=236$ ). The series are formed by one note A followed by 1 to 5 notes B (e.g., AB, $\mathrm{ABB}$ or $\mathrm{ABBB}$ ); note $\mathrm{A}$ may be emitted alone, whereas note $\mathrm{B}$ is only emitted in series. Note A duration ranges from 29 to $56 \mathrm{~ms}$ (mean $41.2 \mathrm{~ms}$; $\mathrm{SD}=4.4 ; \mathrm{N}=145$ ). Notes are formed by 7 to 15 pulses (mean 10.9; $\mathrm{SD}=1.3 ; \mathrm{N}=124$ ), pulse duration ranges from 2 to $11 \mathrm{~ms}$ (mean $3.7 \mathrm{~ms}$; $\mathrm{SD}=0.2 ; \mathrm{N}=163)$, and pulse rate ranges from 194 to 351 pulses per second (mean 265.8; $\mathrm{SD}=20.9 ; \mathrm{N}=124$ ). The dominant frequency ranges from 3,703 to $4,546 \mathrm{~Hz}$ (mean 4,246 Hz; $\mathrm{SD}=165.2 ; \mathrm{N}=145$ ).

Note B duration ranges from 13 to $31 \mathrm{~ms}$ (mean $21.1 \mathrm{~ms}$; $\mathrm{SD}=2.7$; $\mathrm{N}=134$ ), and is formed by 3 to 9 pulses (mean 4.9; $\mathrm{SD}=1.0 ; \mathrm{N}=110$ ). Pulse duration ranges from 2 to $14 \mathrm{~ms}$ (mean $4.2 \mathrm{~ms} ; \mathrm{SD}=0.7 ; \mathrm{N}=113$ ), and pulse rate ranges from 143 to 360 pulses per second (mean 244.5; $\mathrm{SD}=34.9 ; \mathrm{N}=113$ ). The dominant frequency ranges from 3,937 to $4,593 \mathrm{~Hz}$ (mean 4,259 Hz; $\mathrm{SD}=135.4 ; \mathrm{N}=134$ ). When in series (e.g., $\mathrm{ABB}$ ), notes are emitted at rates from 2.63 to 4.73 per second (mean 3.8; $\mathrm{SD}=0.3$; $\mathrm{N}=86$ ). Interval of notes within series ranges from 165 to $320 \mathrm{~ms}$ (mean 221.8; $\mathrm{SD}=18.6 ; \mathrm{N}=117$ ). The amplitude modulation in notes $\mathrm{A}$ and $\mathrm{B}$ is incomplete and variable in shape; in note $\mathrm{B}$, the last pulse is longer than the other ones (Figure 1).

While recording the advertisement calls, two males suddenly decreased their note rate and amplitude in response to the approach of conspecific females. These calls were interpreted as male courtship calls, once the males kept emitting them until the amplexus. The courtship call (Figure 2; $\mathrm{N}=2$ courtship calls) is formed by notes that are similar to notes A of the advertisement call, emitted at a lower amplitude than advertisement calls (Figure 3 ). The calls are formed by 12 and 17 notes, with a note
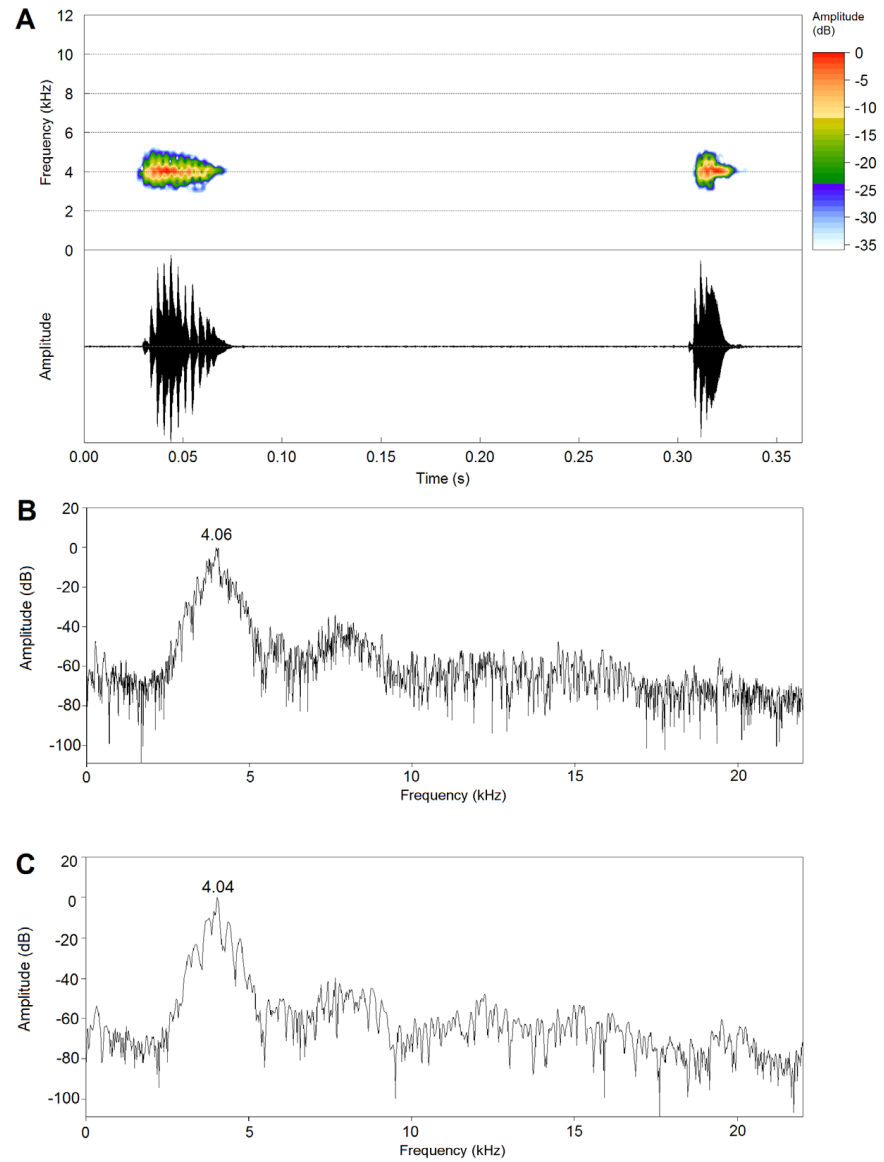

Figure 1 - Advertisement call of Dendropsophus nanus from its type locality (Resistencia, Argentina). A) Spectrogram and its respective oscillogram of the notes $\mathrm{A}$ and $\mathrm{B}, \mathrm{B}$ ) power spectrum of the note $\mathrm{A}$, and $\mathrm{C}$ ) power spectrum of the note $\mathrm{B}$. Sound file: Dendrop_nanus_Resistencia_AR_1a_BFVT_Mtc. 

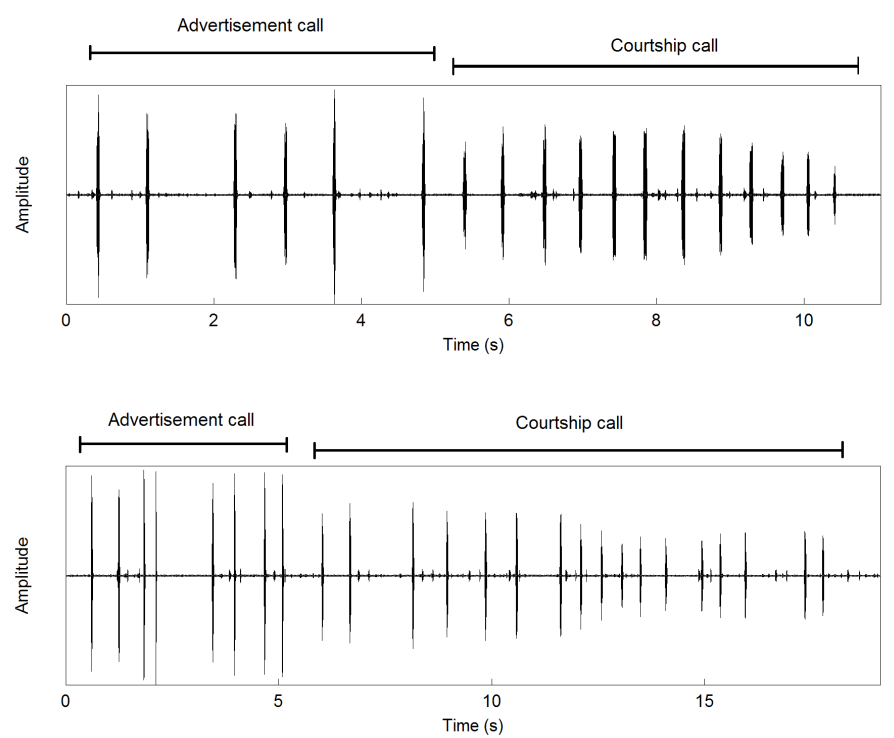

Figure 2-Comparative oscillograms of advertisement calls and male courtship calls from two males of $D$. nanus (Resistencia, Argentina). Sound files: Dendrop nanus Resistencia_AR_5a_BFVT_Mtc; Dendrop_nanus_Resistencia_AR_10a_BFVT_Mtc.

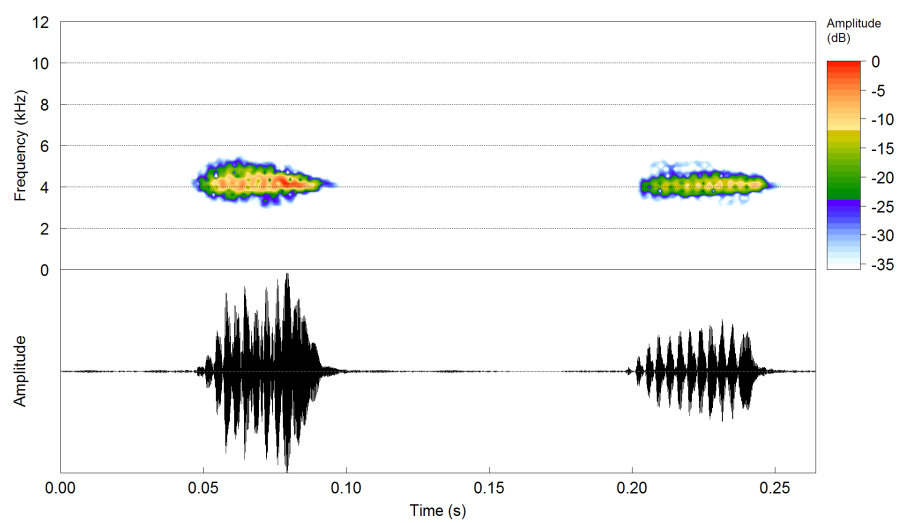

Figure 3 - Spectrogram and its respective oscillogram of a note A of the advertisement call in comparison with a note of the male courtship call. Notice that the main difference is related to the relative sound amplitude of the calls. Sound file: Dendrop_nanus_Resistencia_AR_5a_BFVT_Mtc.

repetition rate of 2.4 and 1.4 notes per second, respectively. Note duration ranges from 37 to $54 \mathrm{~ms}$ (mean $47.1 \mathrm{~ms} ; \mathrm{SD}=1.8 ; \mathrm{N}=29$ ), pulse number from 7 to 13 (mean 11.8; $\mathrm{SD}=0.3 ; \mathrm{N}=29$ ). Pulse duration ranges from 3 to $10 \mathrm{~ms}$ (mean $4.0 \mathrm{~ms} ; \mathrm{SD}=0.1 ; \mathrm{N}=39$ ), and pulse repetition rate from 189 to 289 pulses per second (mean $251.4 \mathrm{~ms} ; \mathrm{SD}=17.1 ; \mathrm{N}=29$ ). The dominant frequency ranges from 3,750 to $4,547 \mathrm{~Hz}$ (mean $4,138 \mathrm{~Hz}$; $\mathrm{SD}=60.7 ; \mathrm{N}=29)$.

\section{Discussion}

Herein, we describe the courtship call of D. nanus composed of similar notes compared to notes A of the advertisement call, but emitted at lower amplitude and lower note repetition rate than in the advertisement call. Courtship calls are probably widespread in anurans, but have not been reported for many species because of the lack of detailed observations in courtship behavior (Wells 2007). Courtships calls may vary from simply lengthening their advertisement calls, increasing calling rates, or by giving calls that are modified versions of the advertisement call, to complex calls composed of more than one type of courtship call. Sometimes, courtship calls are given at lower intensity than advertisement calls, perhaps to avoid alerting other males to the presence of a female (Wells 2007).

The values presented here for the advertisement call of $D$. nanus are in accordance with those described by Martins \& Jim (2003) for a population from the Municipality of Botucatu, State of São Paulo, Brazil, distant about 1,200 km from Resistencia, Argentina. Although Barrio (1967), Basso et al. (1985) and Marquez et al. (1993) did not recognize two different types of notes in the call of $D$. nanus (diphasic call), the values presented by us encompass the ones presented by those authors for spectral and temporal traits of the calls.

In the D. microcephalus group, other seven species have their advertisement calls composed of two types of notes: D. anataliasiasi (Teixeira \& Giaretta 2015), D. gryllatus (Duellman 1973), D. microcephalus (Duellman 1970), D. rhodopeplus (Duellman 1972), D. phlebodes, D. robertmertensi, and D. sartori (Duellman 1968). The advertisement call of D. nanus differs from that of $D$. anataliasiasi by different amplitude modulation (AM) patterns (low AM in D. nanus, high AM in D. anataliasiasi). From those of D. gryllatus (note A: $90-380 \mathrm{~ms}$; note B: 20-80 ms), D. microcephalus (note A: $110-180 \mathrm{~ms}$; note B: $50-140 \mathrm{~ms}$ ), D. rhodopeplus (note A: 100-220 ms), D. phlebodes (note A: 70-160 ms; note B: 40-120 ms), D. robertmertensi (note A: 70-110 ms; note B: 30-60 ms), and D. sartori (note A: 70-90 ms; note B: 40-70 ms) (Duellman 1968, 1970, 1972, 1973, Teixeira \& Giaretta 2015), by a shorter note duration (D. nanus: note A: 29-56 ms; note B: $13-31 \mathrm{~ms})$.

A part from the typical diphasic calls, in some species as Afrixalus brachycnemis Boulenger 1896, the two components of the call are not linked in a single unit or produced in sequence. Males often produce only one component for long periods of time (Backwell 1988). Other species possess more than two notes on the advertisement call, and they may represent a graded set of signals as reported by Smith \& Roberts (2003) for Litoria adelaidensis Gray, 1841. Presumably, diphasic and graded calls have evolved from the simpler monophasic signals, more than once and in different groups, because they offer added advantages in the efficiency of communication. In functionally partitioned calls (Littlejohn \& Harrison 1985; Narins \& Capranica 1978), the male is capable of selectively modifying the proportion of call components in different social contexts (Arak 1983), in order to maximize the efficiency of response to their vocalizations (Backwell 1988).

Narins \& Capranica (1978) and Littlejohn \& Harris (1985) demonstrated that the calls of Eleutherodactylus coqui Tomas, 1966 and Geocrinia victoriana (Boulenger, 1888), composed of two different types of notes, convey separated messages to male and female. While the first note of the call conveys message to males, the second note conveys message to females. Similar experiments have never been conducted to test the functions of the two different note types in species of the $D$. microcephalus group, nor are there available descriptions of male courtship calls for this species group. However, several experiments were conducted to assess the intra-and interspecific acoustic interactions between the syntopic species D. ebraccatus (Cope, 1974), D. microcephalus (Cope, 1886) and D. phlebodes (Stejneger, 1906) (Schwartz \& Wells 1984a, b, Schwartz 1987, Wells \& Schwartz 1984, Wells \& Greer 1981). The results showed that isolated males emitted introductory notes and, when in chorus (in intra- and interspecific interactions), males added secondary and/or aggressive notes to the call as a response to male interactions. Females preferred complex calls (composed of the two note types) instead of those only composed of introductory notes, even if these complex calls were composed of aggressive notes followed by secondary notes (Schwartz \& Wells 1984a, b, Wells \& Schwartz 1984, Schwartz 1987). Wells \& Greer (1981) suggested for D. ebraccatus that the introductory note probably represents the principal female-attracting 
signal, once males respond to the approach of non-calling individuals by emitting a rapid series of primary notes, and the secondary notes may serve a similar function as their structure resembles short segments of primary notes, which is reinforced by the female preference of complex calls for D. microcephalus (Schwartz 1987), but it was also demonstrated that the secondary notes have influence on the interactions between males (Schwartz \& Wells 1984a, b, Wells \& Schwartz 1984, Schwartz 1987).

As the male courtship call of $D$. nanus is composed of similar notes compared to notes A of the advertisement call, it seems that the patterns described for E. coqui and G. victoriana (Narins \& Capranica 1978, Littlejohn \& Harris 1985) are not the same pattern that is described here for D. nanus, whereas the results presented for D. ebraccatus, D. microcephalus, and D. phlebodes (Schwartz \& Wells 1984a, b, Schwartz 1987, Wells \& Schwartz 1984, Wells \& Greer 1981) are more compatible with those presented here, which is expected because these species are more closely related. Once the results presented for D. ebraccatus, D. microcephalus, and $D$. phlebodes are not conclusive with respect to the messages conveyed by the two notes of their advertisement calls, more studies are necessary to understand the functions of the two notes of the call of D. nanus and those of other species in the D. microcephalus group.

\section{Acknowledgement}

We are grateful to Márcia C. D. Santos for field assistance, and to Thiago R. de Carvalho for critically reading the manuscript. To CNPq and FAPEMIG by financial supports. To CNPq by a research grant to AAG, and to CAPES by a doctoral fellowship to BFVT. Permit for collection of specimens was provided by the Dirección de Fauna y Áreas Naturales Protegidas of the Chaco province, Argentina (Guía de tránsito No 4993).

\section{References}

ARAK, A. 1983. Vocal interactions, call matching and territoriality in a sri lankan treefrog, Philautus leucorhinus (Rhacophoridae). Anim. Behav. 31: 292-302.

BACKWELL, P. R. Y. 1988. Functional Partitioning in the Two-Part Call of the Leaf-Folding Frog, Afrixalus brachycnemis. Herpetologica. 44: 1-7.

BARRIO, A. 1967. Sobre la validez de Hyla sanborni K. P. Schmidt e H. uruguaya K. P. Schmidt (Anura, Hylidae). Physis. 26: 521-524.

BASSO, G. N., PERI, S. I. \& DI TADA, I. E. 1985. Revalidación de Hyla sanborni, Schmidt, 1944 (Anura, Hylidae). Cuad. Herp. 1(3): 1-11.

BIOACOUSTIC RESEARCH PROGRAM. 2012. Raven Pro: Interactive Sound Analisys Software. Version 1.5. URL: http://www.birds.cornell.edu/raven

BOULENGER, G. A. 1889. On a collection of batrachians made by Prof. Charles Spegazzini at Colonia Resistencia, South Chaco, Argentine Republic. Annali del Museo Civico di Storia Naturale di Genova. Serie 2, 7: 246-249.

DUELLMAN, W. E. \& FOUQUETTE, Jr. M. J. 1968. Middle American frogs of the Hyla microcephala group. Univ. Kansas Publ. Mus. Nat. Hist. 17(12): 517-557.
DUELLMAN, W. E. 1970. The Hylid Frogs of Middle America. Monographs of the Museum of Natural History, University of Kansas. Lawrence.

DUELLMAN, W. E. 1972. The systematic status and life history of Hyla rhodopepla Günther. Herpetologica 28: 369-375.

DUELLMAN, W. E. 1973. Descriptions of new hylid frogs from Colombia and Ecuador. Herpetologica. 29: 219-227.

DUELLMAN, W. E. \& TRUEB, L. 1986. Biology of Amphibians. McGraw-Hill, New York.

FROST, D. R. 2015. Amphibian Species of the World: an Online Reference. Version 6.0. Available from: http://research.amnh.org/vz/herpetology/amphibia/ (Access in February 2015)

LITTLEJOHN, M. J. 1977. Long range acoustic communication in anurans: An integrated and evolutionary approach. In D. H. Taylor and S. I. Guttman (Eds.), The Reproductive Biology of Amphibians. Plenum Publishing Corporation, New York, p.263-294.

MÁRQUEZ, R., DE LA RIVA, I. \& BOSCH, J. 1993. Advertisement call of Bolivian species of Hyla (Amphibia, Anura, Hylidae). Biotropica, 25(4): 426-443.

MARTINS, I. A. \& JIM, J. 2003. Bioacoustic analysis of advertisement call in Hyla nana and Hyla sanborni in Botucatu, São Paulo, Brazil. Braz. J. Biol. 63: 507-516.

NARINS, P. M. \& CAPRANICA, R. R. 1978. Communicative significance of the two-note call of the treefrog Eleutherodactylus coqui. J. Comp. Physiol. 127:1-9.

R DEVELOPMENT CORE TEAM. 2015. R Foundation for Statistical Computing. Vienna, Austria. Available from: http://www.R-project.org (accessed in 2016).

SCHWARTZ, J. J. \& WELLS, K. D. 1984a. Interspecific acoustic interactions of the neotropical treefrog Hyla ebraccata. Behav. Ecol. Sociobiol. 14: 211-224.

SCHWARTZ, J. J. \& WELLS, K. D. 1984b. Vocal behavior of the neotropical treefrog Hyla phlebodes. Herpetologica 40(4): 452-463.

SCHWARTZ, J. J. 1987. The importance of spectral and temporal properties in species and call recognition in a neotropical treefrog with a complex vocal repertoire. Anim. Behav. 35: 340-347.

SMITH, M. J. \& ROBERTS, J. D. 2003. Call repertoire of an Australian treefrog, Litoria adelaidensis (Anura, Hylidae). J R Soc West Aust. 86: 91-95.

SUEUR, J., AUBIN, T. \& SIMONIS, C. 2008. Seewave, a free modular tool for sound analysis and synthesis. - Bioacoustics, 18: 213-226.

TEIXEIRA, B. F. V. \& GIARETTA, A. A. 2015. Setting a fundament for taxonomy: advertisement calls from the type localities of three species of the Dendropsophus rubicundulus group (Anura: Hylidae). Salamandra 51 (2): 137-146.

WELLS, K. D. 2007. The Ecology and Behaviour of Amphibians. University of Chicago Press, Chicago.

WELLS, K. D. \& GREER, B. J. 1981. Vocal responses to conspecific calls in a neotropical hylid frog, Hyla ebraccata. Copeia 1981 (3): 615-624.

WELLS, K. D. \& SCHWARTZ, J. J. 1984. Vocal communication in a neotropical treefrog, Hyla ebraccata: advertisement call. Anim. Behav. 32: 405-420

Received: $14 / 03 / 2016$

Revised: 12/07/2016

Accepted: 08/09/2016 